\title{
Caring Behavior and Associated Factors Among Nurses in Jambi Teaching Hospital
}

\author{
Muthia Mutmainnah ${ }^{1, *}$ Luri Mekeama $^{2,}$ Yuliana $^{3,}$ Tuti Ariyani ${ }^{4}$ \\ ${ }^{1234}$ Faculty of Medicine and Health Sciences, Jambi University \\ *Email: muthia_mutmainnah@unja.ac.id
}

\begin{abstract}
Nurses play an important role in the implementation of services, especially in the health sector. This service requires nurses to carry out professional nursing care in improving the quality of service. This professional nursing service is supported by the knowledge and competence that comes with caring behavior. The aim of this study was to determine the factors related to the caring behavior of nurses at the RSUD Raden Mattaher Jambi. This research used a correlation analytic study design with a cross-sectional approach with 170 respondents. Data collection using google form and analyzed by chi square. Tthere is a relationship between organizational factors (reward and workload) $(\mathrm{p}=$ $0.001)$, psychological factors (motivation) $(\mathrm{p}=0.005)$, spiritual factors $(\mathrm{p}=0.002)$ with caring behavior of nurses and there is no relationship between age $(p=0.862)$, gender $(p=0.907)$, education $(p=0.524)$, marital status $(p=0.639)$, employment status $(p=0.442)$, length of work $(p=0.162)$ with nurse caring behavior. There is a relationship between organizational factors (appreciation and workload), psychological factors (motivation), spiritual factors with caring behavior of nurses. There is no relationship between gender, age, marital status, education, employment status, length of work and caring behavior of nurses. It is hoped that the hospital can optimize and maintain the quality of nurse caring services.
\end{abstract}

Keywords: Reward, Workload, Motivation, Spiritual, Caring Behavior.

\section{INTRODUCTION}

Caring is the main essence of the nursing profession. The essence of nursing is to provide care for all aspects of human life. Good care provides opportunities for everyone to grow, empower, be independent, and give love. Caring is the ability to be dedicated to humanity. Caring is the primary moral required of nurses. Love and care is an important part that everyone needs.

With the advancement of ICT and evidence-based practice, it has shifted the focus on nursing from a nursing-oriented profession to a technology-oriented service. to balance care, some nursing experts claim that spirituality and caring are the roots of the nursing profession. with this, it can bring nursing to move towards humane nursing. it is achieved to provide loving care and serve everyone biologically, emotionally, socially and spiritually.

This research certainly supports the vision and mission of Jambi University to become a world class entrepreneurship university by providing quality education and producing competitive graduates. This study supports educational programs in shaping caring behavior in nursing students. Nursing practice in the context of caring means also giving time to be with patients, talking and interacting about what is important to them, being receptive and expressive, providing useful experiences for patients. Nurses are health workers who play an important role in the implementation of services, especially in the health sector. This service requires nurses to carry out professional nursing care in improving the quality of service. This professional nursing service is supported by the knowledge and competence that is included with caring behavior. The essence of dynamic nursing is out of caring. The aim of this study was to determine the factors related to the caring behavior of nurses at RSUD Raden Mattaher Jambi.

\section{METHOD}

This research was descriptive correlation with cross sectional approach. The population were all nurses in the Inpatient care unit at Jambi teaching Hospital. There are 170 respondents with a total sampling technique, namely the surgical room with 14 nurses, 28 nurses in 
the Internal Room, 18 nurses in the Heart room, 9 nurses in the neurological room, 6 nurses in the Lung room, 8 nurses in the ENT / Eye room. Children's room with 20 nurses, 27 nurses in Class I, 23 nurses in Class II, 17 nurses in Pinang Masak room. The study was conducted in August 2020 using a google form consisting of a questionnaire on individual factors, organizational factors, psychological factors, spiritual factors, and the Caring Behavior Inventory (CBI-24) questionnaire. Data were analyzed using the chi square test.

\section{RESULTS}

Socio-demographic characteristics of respondents

Based on table 1 , it is found that most of the nurses aged 26 - 35 years, as many as 87 respondents (51.2\%), were female, namely 155 respondents (91.2\%). The education level of nurses is mostly D3, as many as 107 respondents $(62.9 \%)$. Most of the nurses are married as many as 154 respondents $(90.6 \%)$. Most of the nurses were honorary (45.3\%). 93.5\% nurses have worked $>3$ years are as many as 159 respondents

Nurse organizational factors in the high range were 93 respondents $(54.7 \%) .87$ respondents stated that the hospital has given awards to nurses in a high range $(50.9 \%) .88$ respondents stated that the workload was high $(51.8 \%)$. The motivation of nurses in the low range was 99 respondents $(58.2 \%)$.

Spiritual nurses in the high category were 107 respondents $(62.9 \%)$. The caring behavior of nurses in the high category was 110 respondents $(64.7 \%)$.

Table 1. Characteristics of Respondents

Organizational Factors, Psychological Factors, Spiritual Factors, and Nurse Caring Behavior

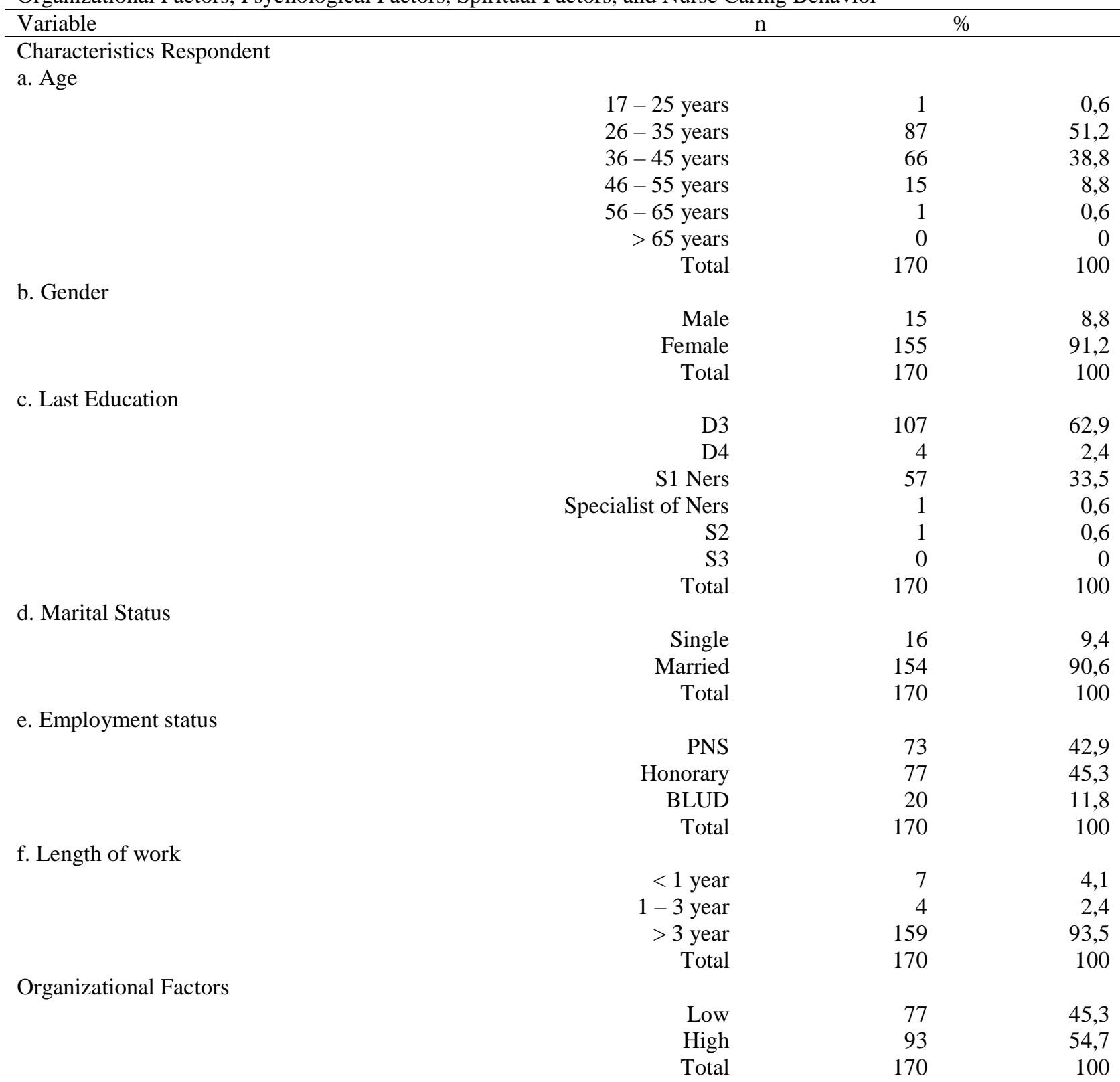


a. Appreciation

\begin{tabular}{|c|c|c|c|}
\hline & Low & 83 & 48,8 \\
\hline & High & 87 & 51,2 \\
\hline & Total & 170 & 100 \\
\hline \multicolumn{4}{|c|}{ b. Workload } \\
\hline & Low & 82 & 48,2 \\
\hline & High & 88 & 51,8 \\
\hline & Total & 170 & 100 \\
\hline \multicolumn{4}{|c|}{ Psychological Factors (Motivation) } \\
\hline & Low & 99 & 58,2 \\
\hline & High & 71 & 41,8 \\
\hline & Total & 170 & 100 \\
\hline \multicolumn{4}{|c|}{ Spiritual Factor } \\
\hline & Low & 63 & 37,1 \\
\hline & High & 107 & 62,9 \\
\hline & Total & 170 & 100 \\
\hline \multicolumn{4}{|c|}{ Caring Behavior } \\
\hline & Low & 60 & 35,3 \\
\hline & High & 110 & 64,7 \\
\hline Total & & 170 & 100 \\
\hline
\end{tabular}

Table 2. Socio-demographic characteristics of respondents, Organizational Factors (Appreciation and Workload), Psychological Factors (Motivation), Spiritual Factors and Nurses' Caring Behavior

\begin{tabular}{|c|c|c|c|c|c|c|c|c|}
\hline \multirow{3}{*}{ Variable } & & \multicolumn{4}{|c|}{ Caring Behavior } & \multirow{2}{*}{\multicolumn{2}{|c|}{ Total }} & \multirow{3}{*}{$p$-value } \\
\hline & & \multicolumn{2}{|c|}{ Low } & \multicolumn{2}{|c|}{ High } & & & \\
\hline & & $\mathrm{n}$ & $\%$ & $\mathrm{n}$ & $\%$ & $\mathrm{n}$ & $\%$ & \\
\hline \multicolumn{9}{|l|}{ Respondents' characteristics } \\
\hline & a. Age & & & & & & & \multirow{8}{*}{0,862} \\
\hline & $17-25$ years & 0 & 0 & 1 & 100 & 1 & 100 & \\
\hline & $26-35$ years & 30 & 34,5 & 57 & 65,5 & 87 & 100 & \\
\hline & $36-45$ years & 24 & 36,4 & 42 & 63,6 & 66 & 100 & \\
\hline & $46-55$ years & 6 & 40 & 9 & 60 & 15 & 100 & \\
\hline & $56-65$ years & 0 & 0 & 1 & 100 & 1 & 100 & \\
\hline & $>65$ years & 0 & 0 & 0 & 0 & 0 & 0 & \\
\hline & Total & 60 & & 110 & & 170 & 100 & \\
\hline \multicolumn{9}{|l|}{ b. Gender } \\
\hline & Male & 6 & 40 & 9 & 60 & 15 & 100 & \multirow{3}{*}{0,907} \\
\hline & Female & 54 & 34,8 & 101 & 65,2 & 155 & 100 & \\
\hline & Total & 60 & & 110 & & 170 & 100 & \\
\hline \multirow[t]{8}{*}{ c. Last Education } & & & & & & & & \multirow[t]{8}{*}{0,524} \\
\hline & D3 & 34 & 31,8 & 73 & 68,2 & 74 & 100 & \\
\hline & D4 & 2 & 50 & 2 & 50 & 4 & 100 & \\
\hline & S1 Ners & 24 & 42,1 & 33 & 57,9 & 57 & 100 & \\
\hline & Ners Spesialist & 0 & 0 & 1 & 100 & 1 & 100 & \\
\hline & S2 & 0 & 0 & 1 & 100 & 1 & 100 & \\
\hline & S3 & 0 & 0 & 0 & 0 & 0 & 0 & \\
\hline & Total & 60 & & 110 & & 170 & 100 & \\
\hline \multirow[t]{4}{*}{ d. Marital Status } & & & & & & & & \multirow[t]{4}{*}{0,639} \\
\hline & Single & 7 & 43,8 & 9 & 56,3 & 16 & 100 & \\
\hline & Married & 53 & 34,4 & 101 & 65,6 & 154 & 100 & \\
\hline & Total & 60 & & 110 & & 170 & 100 & \\
\hline \multirow[t]{5}{*}{ e. Employment status } & & & & & & & & \multirow[t]{5}{*}{0,442} \\
\hline & PNS & 29 & 39,7 & 44 & 60,3 & 73 & 100 & \\
\hline & Honorary & 26 & 33,8 & 51 & 66,2 & 77 & 100 & \\
\hline & BLUD & 5 & 25,0 & 15 & 75,0 & 20 & 100 & \\
\hline & Total & 60 & & 110 & & 170 & 100 & \\
\hline \multirow{2}{*}{ f. Length of work } & & & & & & & & \multirow[t]{2}{*}{0,162} \\
\hline & $<1$ year & 4 & 57,1 & 3 & 42,9 & 7 & 100 & \\
\hline
\end{tabular}




\begin{tabular}{|c|c|c|c|c|c|c|c|c|}
\hline & $1-3$ years & 0 & 0 & 4 & 100 & 4 & 100 & \multirow{7}{*}{0,001} \\
\hline & $>3$ years & 56 & 35,2 & 103 & 64,8 & 159 & 100 & \\
\hline & Total & 60 & & 110 & & 170 & 100 & \\
\hline \multirow[t]{4}{*}{ Organizational Factors } & & & & & & & & \\
\hline & Low & 38 & 49,4 & 39 & 50,6 & 77 & 100 & \\
\hline & High & 22 & 23,7 & 71 & 76,3 & 93 & 100 & \\
\hline & Total & 60 & & 110 & & 170 & 100 & \\
\hline \multicolumn{9}{|l|}{ a. Appreciation } \\
\hline & Low & 38 & 45,8 & 45 & 54,2 & 83 & 100 & \multirow{3}{*}{0,008} \\
\hline & High & 22 & 25,3 & 65 & 74,7 & 87 & 100 & \\
\hline & Total & 60 & & 110 & & 170 & 100 & \\
\hline \multicolumn{9}{|l|}{ b. Workload } \\
\hline & Low & 41 & 50 & 41 & 50 & 82 & 100 & \multirow{3}{*}{0,000} \\
\hline & High & 19 & 21,6 & 69 & 78,4 & 88 & 100 & \\
\hline & Total & 60 & & 110 & & 170 & 100 & \\
\hline \multirow{4}{*}{ Psychological Factors (Motivation) } & & & & & & & & \multirow[t]{4}{*}{0,005} \\
\hline & Low & 44 & 44,4 & 55 & 55,6 & 99 & 100 & \\
\hline & High & 16 & 22,5 & 55 & 77,5 & 71 & 100 & \\
\hline & Total & 60 & & 110 & & 170 & 100 & \\
\hline \multicolumn{9}{|l|}{ Spiritual Factor } \\
\hline & Low & 32 & 50,8 & 31 & 49,2 & 63 & 100 & \multirow{3}{*}{0,002} \\
\hline & High & 28 & 26,2 & 79 & 73,8 & 107 & 100 & \\
\hline & Total & 60 & & 110 & 64,7 & 170 & 100 & \\
\hline
\end{tabular}

Based on table 2, it is found that most nurses in the age range $26-35$ years have high caring as many as 57 respondents $(65.5 \%)$. Statistical tests result using the chisquare test obtained that $p$-value 0.862 ( $p$-value $>\alpha 0.05$ ), which means that there is no relationship between age and nurse caring behavior in the Inpatient Care unit of RSUD Raden Mattaher Jambi.

The majority of female nurses have high caring behavior as many as 101 respondents (65.2\%). Statistical tests result using the chi-square test obtained that $\mathrm{p}$-value 0.907 , its means that there is no relationship between gender and nurse caring behavior in the Inpatient Care unit of RSUD Raden Mattaher Jambi.

Nurses with diploma education have high caring behavior as many as 73 respondents $(68.2 \%)$. Statistical tests result using the chi-square test obtained a p-value of 0.524 which means there is no relationship between education and nurse caring behavior in the Inpatient Care unit of RSUD Raden Mattaher Jambi.

Married nurses have high caring behavior as many as 101 respondents (65.6\%). Statistical tests result using the chi-square test $\mathrm{t}$ obtained $\mathrm{p}$-value 0.639 which means that there is no relationship between marital status and nurse caring behavior in the Inpatient Care unit of RSUD Raden Mattaher Jambi.

Nurses with honorary status have high caring behavior as many as 51 respondents $(66.2 \%)$. Statistical tests result using the chi-square test obtained a p-value of 0.442 which means there is no relationship between employment status and caring behavior of nurses in the Inpatient Care unit of RSUD Raden Mattaher Jambi.

Nurses with a length of work $>3$ years have high caring behavior as many as 103 respondents (64.8\%). Statistical tests result using the chi-square test obtained a p-value of 0.162 , which means there is no relationship between length of work and caring behavior of nurses in the Inpatient Care unit of Raden Mattaher Hospital Jambi Province.

Nurses with high appreciation have high caring behavior as many as 65 respondents $(74.7 \%)$. Statistical tests result using the chi-square test obtained a p-value of 0.008 ( $\mathrm{p}$-value $<\alpha$ 0.05), which means there is a relationship between appreciation and caring behavior of nurses in the Inpatient Care unit of RSUD Raden Mattaher Jambi.

Nurses with high workloads have high caring behavior as many as 69 respondents $(78.4 \%)$. Statistical tests result using the chi-square test obtained p-value 0.000 (p-value $<\alpha$ 0.05), which means there is a relationship between workload and nurse caring behavior in the Inpatient Care unit of RSUD Raden Mattaher Jambi.

Nurses with high organizational factors have high caring behavior as many as 71 respondents (76.3\%). Statistical tests result using the chi-square test obtained a $\mathrm{p}$-value of 0.001 (p-value $<\alpha 0.05$ ), which means there is a relationship between organizational factors and nurse caring behavior in the Inpatient Care unit of RSUD Raden Mattaher Jambi.

Nurses with high motivation have high caring as many as 55 respondents $(77.5 \%)$. The same number with low caring high motivation nurses, namely 55 respondents, but different in percentage, namely $55.6 \%$. Statistical tests result using the chi-square test obtained $\mathrm{p}$-value 0.005 (p-value $<\alpha 0.05$ ), which means there is a relationship between motivation and caring behavior of nurses in the Inpatient Care unit of RSUD Raden Mattaher Jambi.

Nurses with high spirituality have high caring behavior as many as 79 respondents $(73.8 \%)$. Statistical tests result using the chi-square test obtained a p-value of 0.002 which means there is a relationship between 
spirituality and caring behavior of nurses in the Inpatient Care unit of RSUD Raden Mattaher Jambi.

\section{DISSCUSION}

Most of the nurses were in the range of 26-35 years as many as 87 respondents $(51.2 \%)$. The results showed there was no relationship between age and caring behavior with a p-value of 0.862 . However, this study is different from the research conducted by Anggoro (2018) that there is a relationship between age and caring behavior. The longer a person lives, the more mature they will be mentally, physically and socially.[1]

The gender of nurses is mostly female as many as 155 respondents $(91.2 \%)$. Nurse gender is not related to caring behavior with p-value 0.907 . This is supported by Supartin's research which states that there is no difference in the performance of female and male nurses. However, the results of this study contradict the results of Persky's (2008) study that gender has a relationship with the performance of nurses where female nurses have better performance than men. Women have higher sensitivity and caring than men. In this study, there was no relationship between gender variables and nurse caring behavior because there was no difference in the work performed by nurses in the inpatient room. Gender differences are no longer valid in today's society. Male nurses and female nurses have the same obligations and rights.[2]

There are 107 nurses who have D3 education $(62.9 \%)$. Nurse education is not related to nurse caring behavior with $\mathrm{p}$-value 0.524 . This research is in line with research conducted by Rahayu [6] that there is no relationship between education and caring behavior. Education can influence a person's mindset and behavior so that it can affect the quality of the nurse's performance.

Sibandze [3] states that the knowledge that a person gets in education is an experience to develop one's abilities and personality qualities. The higher a person's education level, the higher the desire to utilize knowledge and skills. Education affects the individual mindset. The mindset of individuals with low education will be different from the mindset of highly educated individuals.[3]

There were 154 married nurses (90.6\%). Marital status is not related to nurse caring behavior with $\mathrm{p}$ value 0.639 . The results showed that there was no relationship between marital status and nurse caring behavior. This research is in line with the research conducted by Anggoro (2018) that there is no relationship between marital status and caring behavior of nurses in Dr. H. Soewondo Kendal. Caring behavior of unmarried and married nurses alike. The treatment given to clients is no different and in accordance with the work culture in Raden Mattaher Hospital, Jambi Province, so that marital status does not affect the caring behavior of nurses.[1]

This study is different from the research conducted by Kumajas (2014) in that there is a significant relationship between marital status and the performance of a nurse. The research explains that marriage leads to increased responsibilities and that work remains more valuable and important.[5]

Most of the nurses' employment status were honorary as many as 77 respondents (45.3\%). Employment status is not related to nurse caring behavior with p-value 0.442 . This is in line with research conducted by Yuningsih (2017) which states that there is no relationship between employment status and nurse caring behavior. Employment status should not reduce nurse caring behavior. Nurses, regardless of their employment status, still have to behave in a caring manner towards clients even though the salaries and incentives received by nurses differ between civil servants and honorary. The results of the study are different from research conducted by Desianora (2019) which shows that there is a relationship between employment status and nurse caring behavior.[6]

\subsection{The length of Work}

Most of the nurses (93.5\%). had been worked $>3$ years. Length of work is not related to nurse caring behavior with p-value 0.162 . This research is in line with Demur (2019) that there is no significant relationship between length of work and caring behavior of nurses. The results showed that there was a relationship between the length of work and the caring behavior of nurses. Work experience is not a guarantee for nurses in caring for clients. Nurses who have sufficient tenure and skills, if not supported by motivation, will not have a positive impact. Caring behavior is influenced by the nurse's own understanding and awareness in implementing caring for clients.

A different result was made by Kumajas (2014) that there is a significant relationship between tenure and nurse performance. According to Nursalam (2009) that the more time a nurse works, the more experience the nurse has in providing nursing care that is in accordance with standard or fixed procedures applies.[5]

\subsection{Patient Safety Culture Organizational Factors}

Nurses with high organizational factors have high caring behavior as many as 71 respondents (76.3\%). There is a relationship between organizational factors and nurse caring behavior with p-value 0.001. This organizational factor consists of rewards and workloads. There is a relationship between reward and nurse caring (p-value 0.008). There is a relationship between workload and nurse caring (p-value 0,00). This research is supported by research conducted by Wahyudi (2017) that there is a relationship between appreciation and caring behavior of implementing nurses in the internal care room of Sinjai Hospital. Hospital management needs to reward nurses who have shown hard work to please clients such as salary increases or promotions based on service to clients.

This research is also supported by research conducted by Nyberg (2019) that there is a relationship 
between workload and nurse caring behavior. Generally nurses who have a high workload will experience fatigue. However, nurses at Raden Mattaher Hospital even with high workloads still provide high caring services. This is a positive thing for the hospital, especially in the field of nursing services because caring is the essence of nursing which is based on the values of kindness, care, love for oneself and others as well as spiritual respect for clients (Watson Caring Science Institute).[7]

\subsection{Psychological Factors (Motivation)}

Nurses with high motivation have high caring as many as 55 respondents (77.5\%). There is a relationship between psychological factors (motivation) and nurse caring behavior with a p-value of 0.005 . This is supported by research conducted by Demur (2019) that there is a significant relationship between motivation and nurse caring behavior. Nurses' motivation in caring is high. The important thing to pay attention to in the field of nursing service is to consider the career path system and the competency test model based on caring for nurses and to choose the best caring nurse and room regularly so that the nurse is more motivated

\subsection{Spiritual Factors}

Nurses with high spiritual caring have high as many as 79 respondents $(73.8 \%)$.There is a relationship between spiritual factors and nurse caring behavior with a p-value of 0.002 . This study is in line with the research conducted by Aprilyanti (2017) that there is a relationship between spiritual intelligence and nurse caring behavior in nursing practice in the inpatient room of the Nagan Raya Regional General Hospital. Factors that influence nurse caring are value and trust. Caring is an act of belief that affects every aspect of a nurse's life. The conflict between the individual nurse's beliefs and the values and urges of the case situation can potentially cause distress.[8]

\section{CONCLUSIONS AND SUGGESTIONS}

Based on the results of the study, it can be concluded that most of the nurses aged 26 - 35 years, as many as 87 respondents (51.2\%), were female, namely 155 respondents (91.2). The education level of nurses is mostly D3, as many as 107 respondents (62.9\%). Most of the nurses are married as many as 154 respondents (90.6\%). Most of the nurses were honorary status, as many as 77 respondents $(45.3 \%)$. Nurses who have worked> 3 years are as many as 159 respondents $(93.5 \%)$.

Nurse organizational factors in the high range were 93 respondents $(54.7 \%) .87$ respondents stated that the hospital has given awards to nurses in a high range $(50.9 \%) .88$ respondents stated that the workload was high $(51.8 \%)$. The motivation of nurses in the low range was 99 respondents $(58.2 \%)$. Spiritual nurses in the high category were 107 respondents (62.9\%). The caring behavior of nurses in the high category was 110 respondents $(64.7 \%)$.

There is a relationship between organizational factors (rewards and workload) $(\mathrm{p}=0.001)$, psychological factors (motivation) $(\mathrm{p}=0.005)$, spiritual factors $(p=0.002)$ with caring behavior of nurses and there is no relationship between age $(\mathrm{p}=0.862)$, gender $(\mathrm{p}=0.907)$, education $(\mathrm{p}=0.524)$, marital status $(\mathrm{p}=$ $0.639)$, employment status $(p=0.442)$, length of work ( $p=0.162)$ with nurse caring behavior. It is hoped that the hospital can optimize and maintain the quality of nurse caring services.

\section{AUTHORS' CONTRIBUTIONS}

Muthia Mutmainnah, Luri Mekeama, Yuliana, and were responsible for study conception and design. Luri Mekeama were responsible for data collection and analysis was done. Drafting on the manuscript was done by Yuliana. Administrative activities was done by Tuti Ariyani.

\section{ACKNOWLEDGMENTS}

Thanks to all nurses that and the Raden Mattaher Hospital as a place of research. Thank you to Viqa, Luri Mekeama, and Yuliana for their hard work in registering participants, data collection, and other administrative activities. This research was funded by Universitas Jambi

\section{REFERENCES}

[1] WT., Qurrotul, A., \& Istioningsih. (2018). Hubungan Karakteristik Perawat dengan Caring Behavior [The Relationship between Nurse Characteristics and Caring Behavior]. Jurnal Keperawatan,

[2] Persky G, Nelson JW, Watson J, Bent K. Profile of a nurse effective in caring.Nursin Administration Quarterly. 2008;32(1):15-20.

[3] Sibandze, B. T. (2018). The process bywhich nursesin swaziland develop a values-based practice: a mixed-methods study. George Mason University. Retrieved from ProQuest LLC

[4] Rufaidah, S., Qurrotul, A., \& Istioningsih, I. (2018). Hubungan Caring Behavior Perawat Dengan Los (Length Of Stay) pada Pasien Rawat Inap [Relationship between Nurse Caring Behavior and Loss (Length Of Stay) in Inpatients]. Jurnal Keperawatan, 10(1), 44-52.

[5] Kumajas, F. W., Warouw, H., \& Bawotong, J. (2014). Hubungan karakteristik individu dengan kinerja perawat di ruang rawat inap penyakit dalam RSUD Datoe Binangkang Kabupaten Bolaang Mongondow[The relationship between individual characteristics and the performance of nurses in the internal medicine inpatient room at Datoe Binangkang Hospital, Bolaang Mongondow Regency]. Jurnal Keperawatan, 2(2).

[6] Dewi, R., Afiyanti, Y., dan Rahayuningsih, A. (2017). A Primary Nurse Experiences in Applying Primary Method: A Phenomenology Study. 
Nursing Care Open Access Journal, 4, 376 - 38 Keperawatan, 2, $1-8$

[7] Nyberg, Jan J. (2019). A Caring Approach in Nursing Administration. Colorado. University Press of Colorado

[8] Aprilyanti, S. (2017). Pengaruh Usia dan Masa Kerja Terhadap Produktivitas Kerja [Effect of Age and Working Period on Work Productivity]. Jurnal Sistem dan Manajemen Industri, 1, 68 - 72. 